\title{
EVOLUTION OF ONLINE MAPPING: FROM WEB 1.0 TO WEB 6.0
}

\author{
Karol Król
}

\begin{abstract}
Summary
Web 5.0 performance appears limited only if seen through the prism of technological development. It presents the web as a human-controlled tool, which uses algorithms to attempt to personalize, search, and improve user experience, and to act for or on behalf of a person. Meanwhile, in the Web 6.0 era, the world will be quite unlike what we know today. For instance, it may turn out that Web 6.0 will mean the migration of human consciousness to cyberspace or to an unspecified "cloud" (of data, perhaps?). Will online maps even be needed in such a world? The Web, seen in its current way, is "anchored in metabolism". Web 6.0 endeavours to face up to that. Namely, Web 6.0 aspires to be an independent entity that functions in the Internet ecosystem, depending on the presence of electro-impulses, but without the necessity of "anchoring" on a durable data carrier. This development path could be indicated by the use of artificial intelligence, data analytics and (genetic) algorithms in Web 4.0. At the same time, it is difficult to say whether Web 6.0 will end up as one synthetic, self-conscious organism or a collective of "other identities", i.e. the personalities of individual devices integrated in the network.
\end{abstract}

\section{Keywords}

Web 6.0 • independent existence • Web services • Web Technology • Web Application

\section{Introduction}

The World Wide Web is growing dynamically. Web 2.0, whose main attributes include interactivity, the ability to publish content, and to personalize the layout of the site is evolving and transforming into Web 3.0. The concept of Web 3.0 appeared together with the mobility of devices with Internet access, and applications using data analytics. Web 3.0 enables visualization and processing of data in three dimensions, which are increasingly accompanied by visual geoinformation [Peterson 2012].

Geospatial data and mapping have been instrumental in fuelling the use of the Web to support people and information interactions [Veenendaal 2016]. The Web has also played a foundational role in the provision of online mapping and web GIS. WebGIS technology provides a variety of new tools, such as geo-browsers, geoportals and finally the co-designed GIS. Interoperability and remote geoprocessing are becoming increas- 
ingly important. At the same time, the demand for spatial data and spatial analyses is growing.

The share of geographical data in Internet's resources is constantly growing, among other things, due to the development of free-of-charge location services such as OpenStreetMap or Google Maps. The number and availability of websites presenting spatial data is also increasing. At the same time, the technology of their creation changes, making them increasingly functional and useful. Extensive and programmatically advanced geoinformation websites take over the functions of online maps and atlases [Król 2015a].

Online maps have evolved rapidly over the past two decades. Initially, they took the form of graphic files created by a relatively small group of specialized users. However, soon they evolved into comprehensive and interactive digital maps based on data from many sources and co-designed by crowds of users from around the world [Veenendaal 2016].

The Web is not simply a developing technology for content, but involves people who generate content, communicate and interact in collaborative environments [Hall and Tiropanis 2012]. New user needs evolve, and technology must develop to meet these needs, in turn generating more needs and an iterative cycle of technology development and user/application growth and expansion [Veenendaal 2016].

Understanding the developments in web mapping and the impact on technology, information, and users is important for a number of reasons. It provides a means to understanding the multi-faceted nature of web mapping and GIS developments. It also provides a basis to be able to identify trends and correlations between the various web mapping and related developments. Finally, it provides a means to identify possible future opportunities, developments and directions [Veenendaal 2016].

\section{Material and methods}

The objective of the present work is to analyse the evolution of web mapping in the light of the development of the World Wide Web, starting from Web 1.0, ending with predictions for Web 6.0. The main attributes of online maps published in the Web 1.0 era were verified on the basis of analysing selected websites from 2000-2005, copies of which were obtained from Wayback Machine - Internet Archive (websites were searched using the Keywords: map service). The maps published on current websites, i.e. websites made according to the concepts of Web 2.0 and Web 3.0 were also analysed. In addition, the maps made available on selected mapping services were reviewed.

\section{Web evolution - from Web 1.0 to Web 6.0}

The World Wide Web (commonly known as the web) is not synonymous with the Internet, but it is the most important part thereof. Web can be defined as a technosocial system where people interact based on technological networks [Fuchs et al. 
2010]. The concept of techno-social system refers to a system that strengthens human cognition, communication, and cooperation [Aghaei et al. 2012].

The World Wide Web (WWW) development is divided into several basic stages (Fig. 1). In the zero period, the Web was at an experimental stage (Fig. 1). It is assumed that the inventor of the World Wide Web is the British scientist Tim Berners-Lee, who developed the concept of the WWW in 1989 while working at CERN [Berners-Lee 1994]. On April 30, 1993, CERN released the World Wide Web software in the public domain, which resulted in dynamic development of the web.

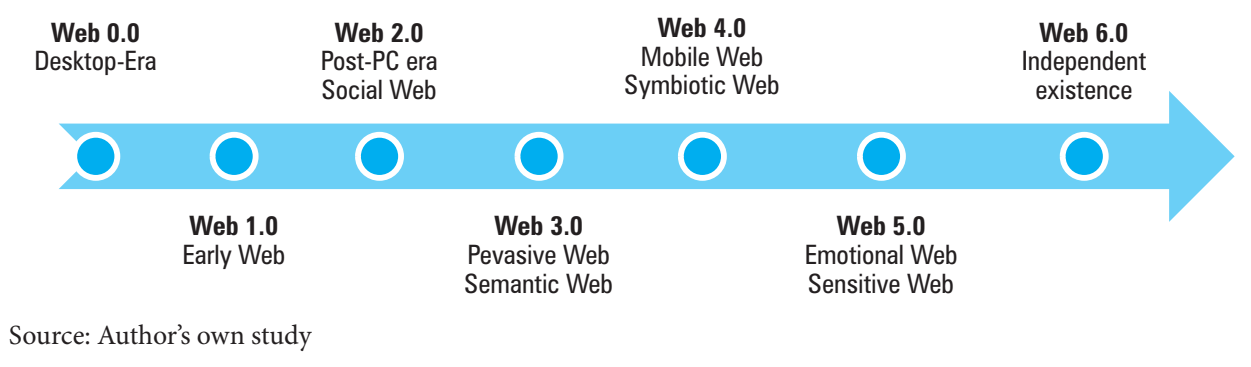

Fig. 1. Diagram of WWW development

The first period of web development is referred to as Web 1.0 (Web of cognition). Web 1.0 was a channel for one-way communication. The role of the average Internet user was limited to reading the information that was presented to him. The second period - Web 2.0 (social Web) - combines the characteristics of Web 2.0 and Web 4.0 (mobile Web). In the third stage, Web 3.0 develops (semantic Web, Web of cooperation).

Web 1.0 involved connecting computers and increasing their combined performance. Web 2.0 is a medium of interpersonal communication, and Web 3.0 technologies support people's cooperation. In the next stage, the network is evolving from Web 4.0 to Web 5.0 [Fuchs et al. 2010]. Hypertext is a technology identified with Web 1.0. Blogs and online discussion panels are Web 2.0 technologies, while Wiki is Web 3.0 technology. We are currently dealing with the development of Web 3.0 technology [Fleerackers and Meyvis 2018].

\section{Desktop Era}

The years 1980-1990 can be called the "Desktop Era", in which desktop computers (PCs) dominated. The Web as it emerged in the early 1990s provided ways to publish and access documents online; the first Web standards were concerned with how documents could be rendered by a browser or how those documents could be transferred over the Internet to be read by users. The Hypertext Transfer Protocol (HTTP) and the Hypertext Mark-up Language (HTML) are considered to have contributed significantly to the success of the 
Web [Hall and Tiropanis 2012]. The first website was dedicated to the World Wide Web project, and it was hosted on a NeXTCube computer [Berners-Lee 1998].

\section{Web 1.0 - early web}

Web 1.0 (the Web of documents) is the first generation of the World Wide Web. It is assumed that the era of Web 1.0 lasted from 1989 to around 2004 or 2005 [Choudhury 2014]. Technologies such as FTP, IRC, Usenet, E-mail, SGML, SQL, MacOS, and File Servers are characteristic for this era. Benito-Osorio et al. [2013] proposed a slightly different temporal subdivision. According to them, the era of Web 1.0 occurred in the years 1990-2000. In the years 2000-2010, Web 2.0 developed (Flash, XML, http, P2P, AJAX, RDF, Java), whereas the era of Web 3.0 is dated to 2010-2020 (mashups, semantic search, widgets). The development of Web 4.0 (semantic databases) and Web 5.0 (intelligent personal agents) is expected in the years 2020-2030.

Web 1.0 is a system of related hypertext documents available over the Internet. Web 1.0 sites were static, passive, "read-only Web", and they were non-interactive [BernersLee et al. 1994]. Brian Merchant [2014] compared the exploration of the first websites to watching a classic black and white silent film. Darcy Dinucci [1999] stated that Web 1.0 is merely an "embryonic phase" that will transform into Web 2.0.

In Web 1.0, a small number of authors created content for the few recipients with access to the Internet. Web 1.0 era sites were mostly made in one of the early specifications of HTML 2.0, HTML 3.0 and HTML 4.0, they were about 700 to 900px wide, which was due to the size of the CRT CRT monitors (15 inches) at the time, and they were often made based on tables or so-called frames [Król 2019a]. In addition, a unique feature of Web 1.0 was the one-way communication model. The publication of the content belonged primarily to users with appropriate qualifications. However, the recipient could only read the information posted without being able to modify or comment on it. Therefore, there was no feedback between the sender and the recipient [Sarowski 2017].

\section{Dot-com bubble and the enthusiasm of the early World Wide Web}

The years 1999-2001 were a period of intense competition in the new technologies sector. Before the stock market collapsed in 2000-2001, enthusiasm for the "new economy" ${ }^{1}$ was widespread, often due to the belief that basic economic principles are losing importance in the Internet ecosystem [Buenstorf and Fornahl 2009]. The development prospects for the IT economy were so encouraging at the time that investors financed dot-com ventures in the form of risk capital without adopting generally accepted practices, despite the fact that at the time it was a little-known sector with unknown success criteria. Many investors eagerly and enthusiastically invested in vari-

1 In 1990-1997 the share of American households with a personal computer increased from 15 to $35 \%$, as possessing one's own PC ceased to be a luxury, and became a necessity. 
ous dot-com companies, especially if they actually had the suffix ".com" in their name. At the peak of the boom, a promising dot-com company could become a public company through IPO (Initial Public Offering) and raise a significant amount of money, even if it never made a profit. Not only that, most companies in the dot-com industry suffered net operating losses as a result of large investments in advertising and promotion to build brand awareness and market share as quickly as possible. Interestingly enough, investors believed that they were acting rationally. This contributed to the creation of the dot-com bubble [Valliere and Peterson 2004].

The dot-com bubble, or IT bubble, describes the phenomenon of a sharp increase in the value of share of stock exchange listed companies related to new (web) technologies, which subsequently in 2000-2001 significantly depreciated, thus leading to the bankruptcy of many companies. The bubble was caused by excessive (irrational) enthusiasm of investors who were convinced that the new economy was "invincible" and that what counts above all is "growth beyond profits". Creative accounting, failed investments, squandering capital, misuse of shareholders' money, misleading investors and other shady schemes played a significant role in inflating the speculative bubble. During the bursting of the dot-com bubble, the value of most online resources dropped by $75 \%$ from their highest values, which totalled around 1.755 trillion USD. Towards the end of the stock market crisis in 2002, dot-com shares lost around 5 trillion USD in market capitalization [Gaither and Chmielewski 2006]. At that time, many investments in the IT services market ended with a spectacular failure. Dot-com companies were less profitable than expected [Kraay and Ventura 2007]. The bursting of the dot-com bubble had major economic and social effects, and is still being analysed today. The dot-com bubble grew relatively quickly and burst rapidly. It was an extraordinary phenomenon. Immediately afterwards, it ended quickly and spectacularly [DeLong and Magin 2006].

\section{Web 2.0 - the user as a first-class object}

Web 2.0 (the post-PC era) is a fashionable term that appeared in 2004-2005 (the term Web 2.0 was used by Darcy DiNucci [1999] as early as 1999), which is commonly used to refer to new phenomena appearing within the web. Although largely a marketing term, the key attributes describing Web 2.0 relate to the development of social networks, two-way communication, various "sticky" technologies, and a significant variety of content types [Cormode and Krishnamurthy 2008]. Web 2.0 is the network as platform, spanning all connected devices. Web 2.0 applications are those that make the most of the intrinsic advantages of that platform: delivering software as a continually-updated service that gets better the more people use it, consuming and remixing data from multiple sources, while providing their own data and services in a form that allows remixing by others, creating network effects through an "architecture of participation," and going beyond the page metaphor of Web 1.0 to deliver rich user experiences [O’Reilly 2005].

Web 2.0 was defined by Dale Dougherty in 2004 as a "wildly read-write Web". Its heyday falls on 2004-2016 [Choudhury 2014]. Web 2.0 is about connecting people 
and creating technologies that are effective for people [O'Reilly 2007]. To describe Web 2.0, terms such as Social Web, people-centric Web or participative Web are used. Technological development has enabled the flourishing of social networking sites and services that have changed the way that the content is managed and interaction happens between the users. Web 2.0 is characterized by Internet applications that facilitate global content production and information exchange. In the Web 2.0 era, all users can generate content, and not just read it (Table 1).

Table 1. Comparison of selected attributes of Web 1.0 and Web 2.0 pertaining to content publication

\begin{tabular}{|c|c|c|}
\hline $\begin{array}{c}\text { Selected attributes } \\
\text { of the web }\end{array}$ & Web 1.0 & Web 2.0 \\
\hline User-orientation & $\begin{array}{l}\text { Less user-centric } \\
\text { Company focus }\end{array}$ & $\begin{array}{l}\text { User as a first-class object } \\
\text { Community focus }\end{array}$ \\
\hline Flagship technology & HTML & AJAX \\
\hline Content management & $\begin{array}{l}\text { FTP (File Transfer Protocol) } \\
\text { Home pages } \\
\text { Owning content }\end{array}$ & $\begin{array}{l}\text { CMS (Content Management System) } \\
\text { Blogs, Wiki } \\
\text { Sharing content }\end{array}$ \\
\hline $\begin{array}{l}\text { Idea of main source of } \\
\text { content }\end{array}$ & $\begin{array}{l}\text { Personal websites. } \\
\text { Curated content. Information } \\
\text { carrier for one user }\end{array}$ & $\begin{array}{l}\text { Blogging. } \\
\text { User generated content. Platform for } \\
\text { many users }\end{array}$ \\
\hline The user's role & $\begin{array}{l}\text { Passive recipient of content. } \\
\text { All visitors are only able to read the } \\
\text { information, whereas all content } \\
\text { and comments are provided by the } \\
\text { publishers }\end{array}$ & $\begin{array}{l}\text { Active contributor of information. } \\
\text { Collaboration between content } \\
\text { editors and those commenting }\end{array}$ \\
\hline $\begin{array}{l}\text { Content updates and } \\
\text { additions }\end{array}$ & $\begin{array}{l}\text { The content is centrally updated in } \\
\text { the specified time intervals. There } \\
\text { is a direct correlation between } \\
\text { popularity of the website and } \\
\text { frequency of updates }\end{array}$ & $\begin{array}{l}\text { The users are producers and } \\
\text { consumers of the content. The } \\
\text { content is updated by the editors. } \\
\text { Websites can be updated while the } \\
\text { users are exploring them }\end{array}$ \\
\hline Types of content & $\begin{array}{l}\text { Typically, text is supplemented } \\
\text { with images, less frequently with } \\
\text { multimedia elements }\end{array}$ & $\begin{array}{l}\text { Website content is a mosaic of a kind: } \\
\text { of audio, video, 3D, text, and images }\end{array}$ \\
\hline $\begin{array}{l}\text { Range of presented } \\
\text { information about the } \\
\text { publisher or the users }\end{array}$ & $\begin{array}{l}\text { Text data, address and registration } \\
\text { data, e.g. e-mail addresses }\end{array}$ & $\begin{array}{l}\text { Personal data on the users, such as } \\
\text { employment, education, occupation } \\
\text { interests, etc. }\end{array}$ \\
\hline
\end{tabular}

Source: Author's own study based on Cormode and Krishnamurthy [2008]

In the Web 2.0 era, a relationship of reciprocity between the user and the Internet service provider is established and enhanced. Web 2.0 is both a platform on which innovative technologies have been built, and a space in which users are treated as first-class 
objects (Table 2). Web 2.0 brings some innovation compared to Web 1.0 in the form of so-called "mashups" that use different data sources [Cormode and Krishnamurthy 2008].

Table 2. Comparison of selected attributes of Web 1.0 and Web 2.0 pertaining to the website structure

\begin{tabular}{|c|c|c|}
\hline $\begin{array}{l}\text { Selected attributes } \\
\text { of the Web }\end{array}$ & Web 1.0 & Web 2.0 \\
\hline Site structure & $\begin{array}{l}\text { Hierarchical structure, home } \\
\text { page (main page) leading to } \\
\text { subsequent pages }\end{array}$ & $\begin{array}{l}\text { Resembling that of social networks, } \\
\text { extending, multithread structures. Shared, } \\
\text { common space }\end{array}$ \\
\hline Website layout & $\begin{array}{l}\text { Identical website's layout for all } \\
\text { users }\end{array}$ & $\begin{array}{l}\text { User-oriented layout. Adjusting the layout } \\
\text { to the user }\end{array}$ \\
\hline $\begin{array}{l}\text { External data } \\
\text { sources }\end{array}$ & $\begin{array}{l}\text { Typically one source of data/ } \\
\text { information uploaded in one } \\
\text { server }\end{array}$ & $\begin{array}{l}\text { Mashups - dynamically generated websites } \\
\text { of many combined sources of information, } \\
\text { uploaded in many servers. Data integration. }\end{array}$ \\
\hline $\begin{array}{l}\text { Time spent on } \\
\text { the site }\end{array}$ & $\begin{array}{l}\text { Limited interaction leads to } \\
\text { the user spending less time } \\
\text { browsing the website }\end{array}$ & $\begin{array}{l}\text { Websites encourage users to spend more } \\
\text { time browsing the content }\end{array}$ \\
\hline $\begin{array}{l}\text { Access } \\
\text { authorisation }\end{array}$ & $\begin{array}{l}\text { Most websites have links to } \\
\text { other, outside websites, and do } \\
\text { not require the users to long in } \\
\text { in order to receive access to the } \\
\text { content. }\end{array}$ & $\begin{array}{l}\text { Promotion of operations within the website. } \\
\text { Numerous resources or functionalities } \\
\text { available upon logging in. Extended } \\
\text { structure of internal links. Users are } \\
\text { encouraged to set-up an account in order to } \\
\text { more fully engaging with the website }\end{array}$ \\
\hline Portalization & $\begin{array}{l}\text { Attempts to develop versatile } \\
\text { websites with many functions } \\
\text { (news, weather, sports) available } \\
\text { from one home page }\end{array}$ & $\begin{array}{l}\text { Attempts to develop all possible functions } \\
\text { within the website, available upon logging } \\
\text { in, so that the users would not have to leave } \\
\text { the website }\end{array}$ \\
\hline User statistics & $\begin{array}{l}\text { Simple user statistics, such as for } \\
\text { instance meter of the number of } \\
\text { visitors to the website }\end{array}$ & $\begin{array}{l}\text { Extended user statistics, such as for instance } \\
\text { Google Analytics. Advance measurements of } \\
\text { website traffic, geolocation, sources of traffic, } \\
\text { gender of visitors, etc. }\end{array}$ \\
\hline
\end{tabular}

Source: Author's own study based on Cormode and Krishnamurthy [2008]

Many websites are difficult to clearly categorize using the "Web 1.0" or "Web 2.0" binary label. However, there is a clear difference between popular Web 2.0 sites, e.g. Facebook and YouTube, and the so-called "old Web". These differences are especially visible in the following areas: (1) technological, e.g. in the scope of scripts used to render websites, (2) structural (purpose and layout of the site) and (3) sociological, e.g. with the emergence of the concepts of "friends" and "groups" [Cormode and Krishnamurthy 2008].

The term Web 2.0 refers to new forms of bottom-up, horizontal cooperation between Internet users, affecting the rules of the functioning of markets, ways of 
constructing and distributing cultural messages, as well as the sphere of politics. However, Web 2.0 is not seen only in superlatives. One of the greatest critics of the idea of Web 2.0 is Andrew Keen [2007], author of the book "Amateur cult: how the Internet destroys culture". In his opinion, Web 2.0 is full of misinformation, manipulation, chaos, and low quality content. It is a place where quantity prevails over quality, ignorance mixes with selfishness, bad taste and mob rule. There is also a view that "Web 2.0" is nothing but a catchy phrase, not associated with any actual improvement in quality [Walkowska 2012].

\section{Web 3.0 - the semantic executing web}

The term Web 3.0 (the pervasive Web, read-write-execute Web) appeared for the first time in 2006 in an article by Jeffrey Zeldman who was associated with technologies such as AJAX [Benito-Osorio et al. 2013]. The starting date of the Web 3.0 era is assumed as 2016 [Choudhury 2014]. Web 3.0 is a neologism used to describe the transformation of a Web into a database (Fig. 2). Web 3.0 allows increasing the availability of content for many applications other than website browsers, the use of artificial intelligence, data analytics, as well as geospatial information and threedimensional visualizations. Web 3.0 uses neural networks and genetic algorithms, with particular emphasis on the acquisition, analysis and processing capacity of user-generated data. A debate is currently underway on the importance and most appropriate definition of Web 3.0.

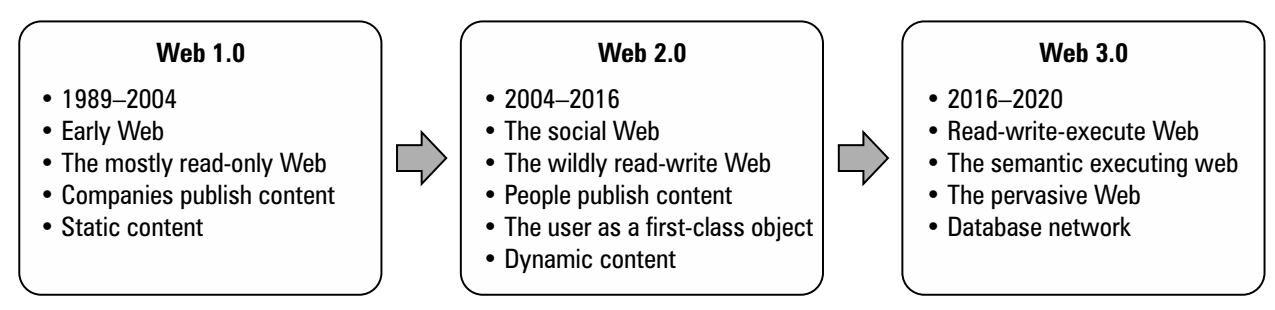

Source: Author's own elaboration based on Choudhury [2014]

Fig. 2. Selected attributes of WWW, from Web 1.0 to Web 3.0

\section{Web 4.0 - mobile Web}

Web 4.0 technology is the mobile version of Web 2.0 and is a real catalyst for Web 2.0 [Fleerackers and Meyvis 2018]. Web 4.0 connects various devices in real time. The development of Web 4.0 aims to connect as many devices as possible to the network. A revolutionary factor in Web 4.0 is a new type of communication, both of people with objects, and objects among themselves (M2M communication, machine to machine). The Internet of Things can be seen as a global infrastructure for the information society, 
enabling the provision of advanced services by combining physical and virtual things [Kwiatkowska 2015].

Web 4.0 is compared to an ultra-intelligent electronic agent and identified with a symbiotic web - the ubiquitous network, where interaction and symbiosis between people and devices is the leitmotif. An intelligent agent is a program that allows you to automate a selected activity, often making decisions during operations, e.g. based on data analysis. An example of Web 4.0 technology is found in the websites that identify users and are therefore able to personalize the information provided.

One of the most important achievements of Web 4.0 is the migration of online functionality to the physical world [Patel 2013]. Among other things, an intelligent agent is capable of performing tasks without strict user control, as well as controlling local or remote operations. Agent technologies are developed in the direction of algorithmic data analysis, learning about user preferences, and performing specific actions (making decisions) on this basis [Sarowski 2017].

\section{Web 5.0 - "anchored in metabolism"}

Although there are various attempts at describing Web 5.0, it remains essentially undefined and speculative [Veenendaal 2016]. The Web 5.0 definition is still under discussion. It is anticipated that Web 5.0 (the sensory and emotive Web; open, linked and intelligent Web) will be based on (emotional) interaction (based on neurotechnology) between people and devices (computers). Web 5.0 will be a kind of (personal) assistant that remains in (constant) contact with the user. Therefore, like Web 4.0, Web 5.0 is referred to as the "symbiotic Web". Currently, the network is "emotionally" neutral, which means that it does not perceive the feelings and emotions of the users [Fleerackers and Meyvis 2019]. Web 5.0 uses neurotechnology, which allows interpreting selected biometric indicators and reading the emotions of users, so that web applications can, for example, change the facial expression of avatars in real time.

Web 5.0 presentation seems to be limited only through the prism of technological development. It presents the web as a human-controlled tool, which uses algorithms to attempt to personalize, search, improve experiences, and act for or on behalf of a person. This is not sufficient. Integrating many devices in one network and programming them so that they "take" actions in the event of predefined conditions will not necessarily have a positive impact on human development, in particular perceived through the prism of people's physicality. What is the added value of a refrigerator ordering shopping from a store, a car that drives itself, or an iron that turns itself off, etc.? Proponents of the Internet of Things will say that this will improve security, enhance (...), boost (...), save time... This may, however, cause some polarization in society. For many people, this environment may be synonymous with some form of enslavement or entrapment. Perhaps for the Internet of Things to become a matter of course, more than one generational change will be needed. All this also has a significant physical aspect - Web 5.0 seems to be still anchored in the human-device-software relationship, connected by cables, sensors or in a wireless network. Web 6.0 seeks to change that. 


\section{Web 6.0 - independent existence}

Fleerackers and Meyvis [2019] diagnosed that there is currently a transition period between Web 2.0 and Web 3.0, although according to a specific "calendar of Web evolution", in 2020, the era of Web 4.0 begins [Benito-Osorio et al. 2013]. Nevertheless, it is difficult to find further predictions in the world literature and answer the question of what Web 6.0 should be. When analysing the attributes of Web 5.0, we might assume that Web 6.0 will be an independent being, capable of independent existence, with the hallmarks of autonomous, independent intelligence.

One can be tempted to set two directions of development for Web 6.0 - towards cyber-biology, or an independent entity. While in the case of Web 4.0 and Web 5.0 there are the concepts of artificial intelligence and virtual agent, in the case of Web 6.0 they aspire to be independent, to the extent that it cannot be described as "artificial". Web 6.0 can take the form of a "different intelligence" or a separate entity that would function in the Internet ecosystem, depending on the presence of electro impulses, without the necessity of "anchoring" on a durable data carrier. This development path could be indicated by the use of artificial intelligence, data analytics and (genetic) algorithms in Web 4.0. It is worth noting, however, that the algorithms work in this case at the direction of the programmer (human), so this type of evolution is unlikely to lead to a rich ecosystem. This raises a number of questions and doubts - after all, life forms known on Earth are based on carbon compounds and complex autocatalytic reactions. Intelligent creatures other than mammals are not known, and the attributes of the conscious are not fully understood [Hołyst 2019].

Would the network itself, understood as technical infrastructure, be necessary for the existence of the Web 6.0 ecosystem? There is a certain danger that Web 6.0, as an "object" or a group of objects - an independent entity (as it is difficult to call it a classically understood organism), could strive for independence and domination, as in the case of the well-known series of futuristic films - Skynet. However, this is the perception of Web 6.0 according to typical human patterns. Web 6.0, as a set of independent objects, could still be based on virtual agents, but these could live in symbiosis with man only voluntarily and by their own choice. There is yet another concept. However, this is not the concept of evolution from Web 4.0 to Web 6.0. It assumes that Web 6.0 technologies will adapt to a changing person, and not as it was before - people change under the influence of technology...

\section{Feed me with working memory - on the evolution of Tierran}

Is Web 6.0 going to be one synthetic, self-aware organism, or a collective of "other identities", i.e. the personalities of individual devices and machines integrated in the network? In 1990, Thomas S. Ray [1991] created a small universe in his computer, which he called Tierra. He placed in it computer programs capable of replication. These programs mutated, evolved, and had their own specific "metabolism". The role of energy was performed by the time of the processor (CPU), and the role of matter, by the RAM memory [Hołyst 2019]. The Tierra simulator was run on a virtual machine 
and software written in C. In Tierra, there were Tierrans, the so-called "Creatures", i.e., self-replicating algorithms that reside in RAM. RAM was assigned the role of so-called soup. It was an analogy to the so-called primary soup or organic soup, i.e. a hypothetical mixture of organic compounds that, according to one theory, gave rise to life on Earth. Programs that as a result of mutation lost the replication procedure used the procedure of copying neighbours, acting as parasites of a kind. When the operating system was looking for a block of free memory of the desired size, however, such a block was not available, or when the "soup" was filling up - the system called a reaper. Reaper "killed cells" at the top of the list of creatures (digital beings) for annihilation, that is, it erased programs, thus freeing RAM resources [Tierra 1991].

The operating system in the world of Tierra provided, among other things, control over the course of evolution and an extensive monitoring system. It kept a register of "births and deaths", sequenced the code of each creature, and maintained a gene bank of successful genomes. It also recorded types of interactions between the "creatures" [Tierra 1991].

Critics of the Tierra ecosystem dismiss it for the lack of an evolutionary factor, i.e. the increase in the complexity of digital organisms. As with other digital evolution systems, the Tierra ecosystem has finally reached the point where "newness" ceased to be created and the entire system looped and ceased to "evolved" [Bedau and McCaskill 2000]. It is worth noting here that the advantage of computer evolution over biological evolution lies in the speed of changes taking place. The former can be millions of times faster than the latter, which means that the future of life research can shift from biological sciences to computer science and cyber-biology [Hołyst 2019].

\section{Maps online}

Spatial information has always accompanied people, as a discipline mainly associated with the geographical location of selected objects. Spatial information was originally presented using drawings, and then using maps of varying quality. From the mid1990s, traditional (analogue) maps were gradually replaced by digital maps, both vector-based and raster-based, but also hybrid. Currently, spatial data are collected in computer databases, which provide a number of additional possibilities of using data, for instance through network services, such as WMS [Iosifescu, Enescu et al. 2015]. In addition, the development of information technologies has meant that $3 \mathrm{D}$ data presentations are increasingly used [Siejka et al. 2014, Król and Prus 2018]. Visualizations are used, among other things, for the creation of noise maps, propagation of radio waves, corridors and air circulation, simulation of anti-terrorist operations, natural disasters, military operations, and many others. In addition, software development makes it possible to visualize and analyse space in time, as well as modify maps and share them with other users.

The concept of online cartography is associated with the design, production, display and use of maps on the Internet [Kraak 2001]. The IT revolution has replaced traditional analogue maps with a spatial database and a set of visualization tools. The advent 
of the World Wide Web has changed the way the maps are created, published and used. Currently, many maps are available and viewed by users via the Internet [Peterson 2003, Black and Cartwright 2005].

The traditional analogue map is created during the process of editing and cartographic reproduction. It can be saved as a raster image file and made available in digital form online. In the early stages of the Internet, this was a popular form of simple map presentation on websites, which over time gave way to interactive map applications [Kowalczyk and Pokojski 2018]. In addition, significant changes have occurred in the use of maps as a result of the use of computers and GIS-type software. One of these changes was the transition from public use of maps to individual, "social network" use. Maps ceased to be used only for the presentation of known facts and began to be used to discover previously unknown regularities. Another change in the use of maps is associated with an increase in their interactivity.

Along with the development of the Internet, the degree of map interactivity and functionality has changed, which significantly affected the scope of their use. Online maps have changed their function - from information to visualization. Initially, maps on the Internet enabled browsing and comparing content. Later, they enabled the ordering, sorting, extracting and hiding content, and finally determining cause-effect relationships [Crampton 2002]. More complex map applications facilitate conducting complex spatial analyses and ensure a high degree of interactivity [Andrienko and Andrienko 1999]. The interaction determines the relationship between the map and the user. It assumes the possibility of "map impact" on the recipient of information, and the impact of the recipient (user) on the scope and form of information presented on the map [Macioch and Malmon 2010]. In addition, digital maps are becoming more and more detailed and perfect [Zygmunt 2017].

In general, online maps can be divided into static and dynamic maps, or into browsing-only maps and interactive maps [Kraak 2001]. Maps on the Internet can be "closed and made" (Web cartography) or "open" (Web-enabled cartography). Editing or personalizing the former is not possible, while the latter can be modified, even by adding your own content (objects, information, etc.) [Król and Prus 2017].

\section{Description of online maps from Web 1.0 to Web 5.0}

The Web is very important medium for the distribution of cartographic products. WWW allows for a dynamic and interactive dissemination of geospatial data. This results in new mapping techniques as well as new possibilities for uses had that not been seen before with traditional printed maps and most on-screen maps [Cerba and Cepicky 2012].

In the Web 1.0 era, maps published on websites were mostly static in character. They were raster files, i.e. graphics inserted directly in the HTML code using the <IMG> tag. They gave the user the opportunity to read the information [Król 2015b]. These graphics were often scans of various analogue maps, including official and cartographic publications. Some of them constituted merely a kind of presentation of the location of 
the object in space - a scan of a freehand drawing. Still other "maps" were created by the users themselves, using various graphics programs (Fig. 3). This era is equivalent to the first generation of online maps [Plewe 2007].

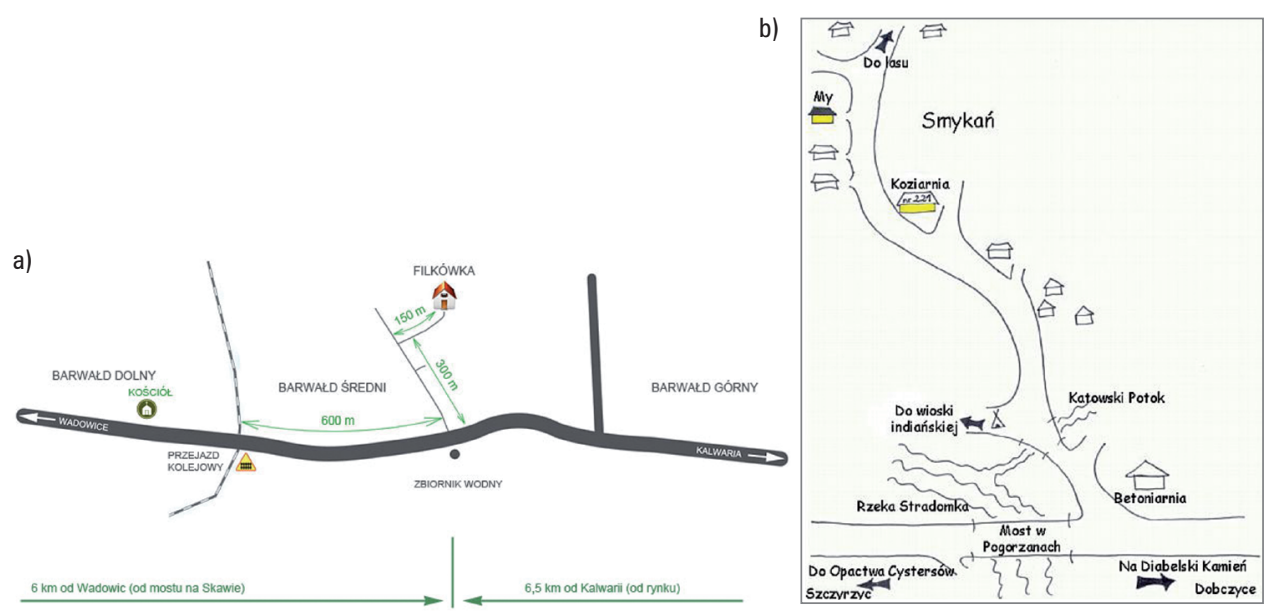

Source: filkowka.pl, downloaded from Internet Archive, at present the website is obsolete (accessed: 26.06.2019), ekoagro.pl (accessed: 26.06.2019)

Fig. 3. Access diagram to "Filkówka" object (3a) and access diagram to "Koziarnia" object (3b). Websites developed using Web 1.0 technology

An example of an amateur map service, which was made in the Web 1.0 era, based on frames (HTML attribute - <frame>) is "Polski serwis mapowy" ("Polish map service"). The first copy of the website available in the Internet Archive dates to the year 2004 (Web 1.0), and the last, to March 2015. The site was hosted on a free server at the Internet address - http://scanmap.w.interia.pl/. Scans of printed publications were made available on the website. According to the publisher's assurances, the maps were scanned at a minimum resolution of $300 \mathrm{dpi}$ and saved as a JPG file (90\% compression rate). Analysis of archival copies showed that this site was of an amateur nature. In addition, it was not properly updated. Currently, the content of the website can be read only by exploring online archives, which is associated with the termination of the provision of free hosting services by the Interia Group.

The evolution of map services can also be traced by analysing the history of Targeo. pl. The first copies of the Targeo.pl website available on the Internet Archives date to 2005. At that time, the website was still under development, and consisted of a start (home) page. At the time, Targeo was presented as an innovative IT platform combining GPS monitoring, high-quality digital maps, management of mobile employees, and satellite navigation (according to Indigo). The first copy of the map service appeared on the Internet Archives only on February 10, 2007. The website was described as "Map of Poland with detailed addresses in 452 locations". In subsequent years, the website 
was modified and expanded to include search functions on the map as well as route mapping.

The development of information technologies, including geoinformation technologies and online maps, is heading towards a new generation of web as a collection of related documents available via the Internet. Web 2.0 is a new era of geoinformation. Subsequent stages of web development (Web 2.0, Web 3.0, Semantic Web etc.) are associated with terms such as user-oriented applications, information exchange, and teamwork. However, interoperability is particularly important, as it is a prerequisite for the functioning of the complete system and its components [Cerba and Cepicky 2012]. Dynamic maps using DHTML, Common Gateway Interface (CGI), Java and ActiveX technologies enabled users to view maps that were dynamically generated on the server, according to the user's preferences. Users had a few simple map parameters to choose from regarding content, options and layout [Veenendaal 2016].

The development and availability of Internet technologies, including the ability to create cartographic components of websites, has created a new group of "users-producers" or "users-creators" ("produsers"). Produsage is a term that was first used by Axel Bruns [2007]. The author describes the changes taking place in the way web resources are used, and presents an active user who, from a passive recipient, turns into the creator of content made available on the Internet. A characteristic feature of "produsers" is the inclination to connect with the community and work together on the content created. Usually, it is based on volunteering, and participation in "produsage" projects is voluntary [Król 2015c]. In addition, universal access to open data resources and geoinformatic tools has developed a current of geographical information created by the user community (Volunteered Geographic Information, VGI) [Goodchild 2007].

In the spatial scene, OpenStreetMap and Google maps mash-ups have shown the power of community-based web mapping. The openness of these applications also has a downside, namely the loosely defined semantics of the information held in the same tagged information. In the Web 2.0, the building of concepts and annotation of information sources is community-controlled. These communities are typically comprised of many users and information providers [Lemmens i Deng 2008]. The Web 2.0 era also brings with it other problems such as: lack of uniform and orderly data, no updating of geographical data, difficulties in ensuring the security and privacy of geoinformation services, and doubts regarding property rights [Li and Shao 2009].

In the Web 2.0 era, the image tiling technology combined with AJAX technology allowed online maps to be delivered to a user in a continuous and responsive manner. While the downloading of image tiles occurs in the background in an asynchronous fashion, the user experiences no wait time while viewing a continuously refreshing and emerging image. This increased the focus on the user experience and paved the way for the next web mapping era. It also marked the start of the Web 2.0 developments and opened the way for more users to participate in both mapping retrieval and data creation activities [Veenendaal 2016].

In the Web 2.0 era, Google Earth applications, Bing Maps Platform and grid technology emerged, as well as a large number of wizards and generators that allow the 
users create their own maps in an automated manner. All this made geographical information popular and widespread [Król 2018]. In the era of Web 2.0, online maps are dynamic and are often implemented in the structure of a hypertext document using the so-called $<$ iframe $>$ (embed a map) or with the help of programming interfaces (API). The dynamic map is interactive, allows the user to explore the entire globe, and can be extended with selected functionalities available at the user's request, e.g. route calculation or searching for objects. Often, various map components created using JavaScript programming libraries are also used, such as for instance jQuery (Fig. 4) [Król and Szomorova 2015, Król 2019b].

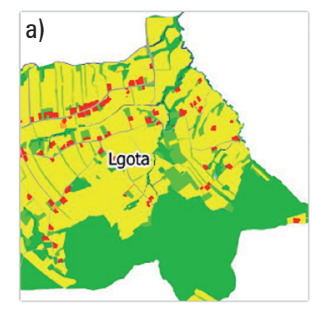

Resize image Resize mage

Rotate counterclockwise

Export
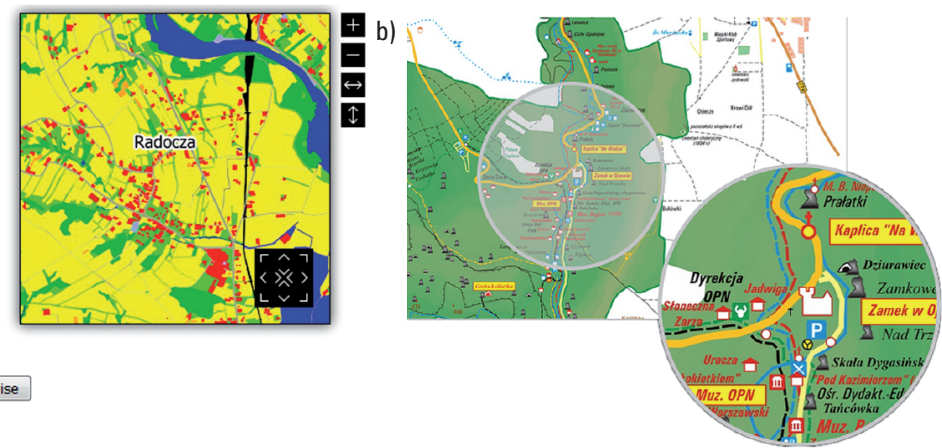

Source: Author's own study [Król 2019b].

Fig. 4. Map of spatial diversity of farmlands in Tomice municipality, which can be browsed by means of navigation buttons: (4a) Cropit script and Cropping script. Fragment of tourism map of Ojców National Park presented in window of interactive lens (4b), jfMagnify screenshots

In the Web 2.0 era, mashup type services became widespread. Web mashup is a web page (or web site) that combines information and services from multiple sources on the web. It is easier and quicker to create mashups than to code applications from scratch in traditional ways; this capability is one of the most valuable features of Web 2.0 [Ritt and Hörtler 2008]. Thematic maps (also called special-purpose maps, single-topic maps, statistical maps) are also common. Many Internet users work with thematic maps and use them as a source of information or a way of presenting data.

A characteristic of Web 2.0 and Web 3.0 is the extensive network services. Network services enable automated processing of large amounts of data and quick response to data changes. They build applications operating in real time; they support the use of external resources, and elimination of unnecessary data resources and software. Web services enable an exploitation of software applications available from web servers. Users can make use of them through clients supporting a concrete standard interface of web services. In geoinformation sciences including cartography, the most used web services are standardized by the Open Geospatial Consortium (OGC) [Cerba and Cepicky 2012]. 
The intelligent web mapping era embraces semantic technologies and smart devices that provide context and customisation to the information delivered to users and applications. This era is still presently in its early stages, with the goal to provide relevant information to users in the appropriate context, e.g. geographic, temporal or semantic. This era also encompasses the semantic web and Web 3.0 developments [Veenendaal 2016].

\section{Conclusions}

Sites created before 2001 (according to the concept of Web 1.0) were usually static. They served as "business cards", online (hyper) boards presenting a given content. Mostly they were poorly functional and lacked interaction. The first maps placed on websites thus developed took the form of static computer graphics. The evolution and availability of geoinformation technologies have had an impact on the development of not only websites themselves but also online maps. The latter have gained an interactive and dynamic character. While the raster presents a limited area of space, due to the size of the graphic file expressed in both megabytes and pixels, the dynamic maps facilitate spatial exploration of the entire globe, and interactive map resources are fully stored on the service provider's servers (client-server architecture). All tasks are also performed on the server side. Only a working Internet browser is required from the user.

The World Wide Web is increasingly used to communicate with applications. The document network has evolved into a data network. Web 1.0 was primarily a publishing and transactional environment. Web 1.0 was focused on connecting documents (resources) and accessing the network. Web 2.0 is a space where users contribute to the value (of websites). Web 2.0 consists of connecting people who place their individual "I" in the user interface, and their social "we" in the network of social participation. Web 3.0 is a semantic space in which machine intelligence combines with human intelligence. The semantic web enables data sharing and recycling. Web 4.0 is a mobile space where users as well as real and virtual objects are integrated to create new values. In turn, Web 5.0 is a sensory emotional space that moves the network from an "emotionally poor" environment to a space of rich interactions [Kambil 2008]. In the Web 6.0 era, the world will not be like what we know today. It may turn out that Web 6.0 will mean the migration of human consciousness to cyberspace or an unspecified "cloud". Will there be a need for internet maps in such a world?

Funded with a subsidy of the Ministry of Science and Higher Education for the University of Agriculture in Krakow for 2020.

\section{References}

Aghaei S., Nematbakhsh M.A., Farsani H.K. 2012. Evolution of the world wide web: From Web 1.0 to Web 4.0. International Journal of Web \& Semantic Technology, 3(1), 1-10. https://doi. org/10.5121/ijwest.2012.3101

Andrienko G.L., Andrienko N. 1999. Interactive maps for visual data exploration. Intern. J. of Geogr. Inform. Science, 13(4), 355-374. https://doi.org/10.1080/136588199241247 
Bedau M.A., McCaskill J.S., Packard N.H., Rasmussen S., Adami C., Green D.G., Ikegami T., Kaneko K., Ray T.S. 2000. Open problems in artificial life. Artificial Life, 6(4), 363-376. https://doi.org/10.1162/106454600300103683

Benito-Osorio D., Peris-Ortiz M., Armengot C.R., Colino A. 2013. Web 5.0: the future of emotional competences in higher education. Global Business Perspectives, 1(3), 274-287. https://doi.org/10.1007/s40196-013-0016-5

Berners-Lee T., Cailliau A., Luotonen H.F., Nielsen A. 1994. The World-Wide Web. Communications of the ACM, 37(8), 76-82. http://dx.doi.org/10.1145/179606.179671

Berners-Lee T. 1998. The World Wide Web: A very short personal historyW3C, http://bit. ly/2xFhjgY

Black M.A., Cartwright W.E. 2005. Web cartography \& Web-enabled geographic information systems (GIS). New possibilities, new challenges. The 22nd International Cartographic Conference, A Coruña, Spain, 9-16 July 2005. http://bit.ly/2JAaAKQ

Bruns A. 2007. Produsage: Towards a Broader Framework for User-Led Content Creation. In Creativity and Cognition. Proceedings of the 6th ACM SIGCHI Conference on Creativity \& Cognition, ACM, Washington, DC.

Buenstorf G., Fornahl D. 2009. B2C-bubble to cluster: the dot-com boom, spin-off entrepreneurship, and regional agglomeration. Journal of Evolutionary Economics, 19(3), 349-378.

Cerba O., Cepicky J. 2012. Web services for thematic maps. In Online maps with APIs and webservices, 141-155. Springer, Berlin, Heidelberg.

Choudhury N. 2014. World wide web and its journey from web 1.0 to web 4.0. International Journal of Computer Science and Information Technologies, 5(6), 8096-8100.

Cormode G., Krishnamurthy B. 2008. Key differences between Web 1.0 and Web 2.0. First Monday, 13(6). https://doi.org/10.5210/fm.v13i6.2125

Crampton J.W. 2002. Interactivity types in geographic visualization. Cartography and Geogr. Inform. Science, 29(2), 85-98.

DeLong J.B., Magin K. 2006. A short note on the size of the dot-com bubble (No. w12011). National Bureau of Economic Research.

DiNucci D. 1999. Fragmented future. Print, 53(4), 32, 220-222.

Fleerackers T., Meyvis M. 2018. Digital Evolution. Past, present and future outlook of digital technology. Flat World Blog. https://flatworldbusiness.wordpress.com/digital-evolution/ [accessed: 24 January 2020].

Fleerackers T., Meyvis M. 2019. Web 1.0 vs Web 2.0 vs Web 3.0 vs Web 4.0 vs Web 5.0 - A bird's eye on the evolution and definition. Flat World Blog. http://bit.ly/2X87liz [accessed: 24 January 2020].

Fuchs C., Hofkirchner W., Schafranek M., Raffl C., Sandoval M., Bichler R. 2010. Theoretical foundations of the web: cognition, communication, and co-operation. Towards an understanding of Web 1.0, 2.0, 3.0. Future Internet, 2(1), 41-59. https://doi.org/10.3390/ fi2010041

Gaither Ch., Chmielewski D.C. 2006. Fears of Dot-Com Crash, Version 2.0. Los Angeles Times.

Goodchild M.F. 2007. Citizens as sensors: the world of volunteered geography. GeoJournal, 69(4), 211-221. https://doi.org/10.1007/s10708-007-9111-y

Hall W., Tiropanis T. 2012. Web evolution and Web Science. Computer Networks, 56, 38593865. http://dx.doi.org/10.1016/j.comnet.2012.10.004

Hołyst R. 2019. Życie w pamięci RAM - ewolucja cyberorganizmów. Instytut Chemii Fizycznej PAN i Szkoła Nauk Ścisłych. http://bit.ly/2LJEa3w [accessed: 24 January 2020].

Iosifescu Enescu I., Panchaud N.H., Heitzler M., Iosifescu Enescu C.M., Hurni L. 2015. Towards Better WMS Maps Through the Use of the Styled Layer Descriptor and Cartographic 
Conflict Resolution for Linear Features. The Cartographic Journal, 52(2), 125-136. https:// doi.org/10.1080/00087041.2015.1119468

Kambil A. 2008. What is your Web 5.0 strategy? Journal of Business Strategy, 29(6), 56-58.

Keen A. 2007. Kult amatora. Jak Internet niszczy kulturę. Wydawnictwa Akademickie i Profesjonalne, Warszawa.

Kowalczyk A., Pokojski W. 2018. Nowe technologie w turystyce: przejście od map analogowych do map cyfrowych. Folia Turistica, 48, 13-40. https://doi.org/10.5604/01.3001.0012. 7688

Kraak M.-J. 2001. Settings and methods for web cartography. [In:] Web cartography. Developments and prospects, ed. M.-J. Kraak, A. Brown. Taylor \& Francis, London-New York.

Kraay A., Ventura J. 2007. The Dot-Com Bubble, the Bush Deficits, and the U.S. Current Account. In G7 Current Account Imbalances: Sustainability and Adjustment, 457-495. University of Chicago Press. http://www.nber.org/chapters/c0124

Król K. 2015a. Ocena wybranych technik tworzenia interaktywnych map lokalizacji obiektów przestrzennych. Acta Sci. Pol., ser. Formatio Circumiectus, 14(4), 49-59. https://doi. org/10.15576/ASP.FC/2015.14.4.49

Król K. 2015b. Tworzenie statycznych map obiektów przestrzennych z wykorzystaniem metody parametryzacji adresu zasobu sieciowego - analiza porównawcza. Acta Sci. Pol., ser. Formatio Circumiectus, 14(4), 61-73. https://doi.org/10.15576/ASP.FC/2015.14.4.61

Król K. 2015c. Conception of a touristic map and nature protection forms created with use of open data sources and free software on a Grybów commune example. Geomatics, Landmanagement and Landscape (GLL), 4, 49-59. https://doi.org/10.15576/GLL/2015.4.49

Król K. 2018. Wizards and generators in teaching information technologies to students of engineering. Engineering for Rural Development, 17, 1260-1269. https://doi.org/10.22616/ ERDev2018.17.N502

Król K. 2019a. Forgotten agritourism: abandoned websites in the promotion of rural tourism in Poland. Journal of Hospitality and Tourism Technology, 10(3), 461-472. https://doi. org/10.1108/JHTT-09-2018-0092.

Król K. 2019b. Zoomlens - graphic form of data presentation on a web map, comparison of chosen tool and usage examples. Engineering for Rural Development, 18, 1641-1648. https:// doi.org/10.22616/ERDev2019.18.N002

Król K., Prus B. 2017. Dynamic presentation of static maps using GIS and jQuery JavaScript tools taking data of soil maps in Poland as an example. Geographic Information Systems Conference and Exhibition "Gis Odyssey" 2017, 203-212.

Król K., Prus B. 2018. Application of interactive charts in the evaluation of socio-economic development of regions. The case of Poland. Acta Sci. Pol., ser. Formatio Circumiectus, 17(3), 141-151. https://doi.org/10.15576/ASP.FC/2018.17.3.141

Król K., Szomorova L. 2015. The possibilities of using chosen jQuery JavaScript components in creating interactive maps. Geomatics, Landmanagement and Landscape (GLL), 2, 45-54. https://doi.org/10.15576/gll/2015.2.45

Kwiatkowska E.M. 2014. Rozwój Internetu rzeczy - szanse i zagrożenia. Internetowy Kwartalnik Antymonopolowy i Regulacyjny, 8(3), 60-70.

Lemmens R., Deng D. 2008. Web 2.0 and semantic web: Clarifying the meaning of spatial features. Semantic Web meets Geospatial Applications, AGILE.

Li D., Shao Z. 2009. The new era for geo-information. Science in China Series F: Information Sciences, 52(7), 1233-1242. https://doi.org/10.1007/s11432-009-0122-9

Macioch A., Malmon G. 2010. Funkcje interaktywne współczesnych map elektronicznych. Polski Przegląd Kartograficzny, 42(4), 331-353. 
Merchant B. 2014. What It Was Like to Surf the Web in 1989. Motherboard Blog. https://www. vice.com/en_us/article/8qxg4x/surfing-the-web-circa-1989

O’Reilly T. 2005. Web 2.0: compact definition. O’Reilly Media. http://radar.oreilly.com/2005/10/ web-20-compact-definition.html [accessed: 24 January 2020].

O'Reilly T. 2007. What is Web 2.0: Design patterns and business models for the next generation of software. Communications \& Strategies, 65, 17-37.

Patel K. 2013. Incremental journey for World Wide Web: introduced with Web 1.0 to recent Web 5.0 - a survey paper. International Journal of Advanced Research in Computer Science and Software Engineering, 3(10), 410-417.

Peterson M.P. 2003. Maps and the Internet: An Introduction. [In:] Maps and the Internet, ed. M.P. Peterson. Elsevier Science, Oxford.

Peterson M.P. 2012. Online Maps with APIs and WebServices. Springer Science \& Business Media.

Plewe B. 2007. Web cartography in the United States. Cartography and Geographic Information Science, 34(2), 133-136. https://doi.org/10.1559/152304007781002235

Ray T.S. 1991. An approach to the synthesis of life. [In:] Artificial Life II, eds. C.G. Langton, C. Taylor, J.D. Farmer, S. Rasmussen. Addison-Wesley, New York.

Ritt A., Hörtler P. 2008. Security Aspects in Web 2.0 Mashup Systems, Technology, Altenbergerstrabe 69, 4020. Linz, Austria. http://bit.ly/2xbZ56u [accessed: 24 January 2020].

Sarowski Ł. 2017. Od Internetu Web 1.0 do Internetu Web 4.0 - ewolucja form przestrzeni komunikacyjnych w globalnej sieci. Rozprawy Społeczne, 11(1), 32-39.

Siejka M., Ślusarski M., Zygmunt M. 2014. 3D+time Cadastre, possibility of implementation in Poland. Survey Review, 46(335), 79-89. https://doi.org/10.1179/1752270613Y.0000000067

Tierra 1991. Tierra.doc 17-3-98 documentation for the Tierra Simulator. http://life.ou.edu/ pubs/doc/index.html\#What [accessed: 24 January 2020].

Valliere D., Peterson R. 2004. Inflating the bubble: examining dot-com investor behaviour. Venture Capital, 6(1), 1-22. https://doi.org/10.1080/1369106032000152452

Veenendaal B. 2016. Eras of Web mapping developments: past, present and future. International Archives of the Photogrammetry, Remote Sensing \& Spatial Information Sciences, 41, 247-252. https://doi.org/10.5194/isprsarchives-XLI-B4-247-2016

Walkowska J. 2012. Jeśli nie Web 2.0, to co? Biuletyn EBIB, 2(129), Koniec 2.0? http://bit.ly/325rauw [accessed: 24 January 2020].

Zeldman J. 2006. Web 3.0. A List Apart. http://www.alistapart.com/articles/web3point0 [accessed: 24 January 2020].

Zygmunt M. 2017. Circular arc approximation using polygons. Journal of Computational and Applied Mathematics, 322, 81-85. https://doi.org/10.1016/j.cam.2017.03.030

\author{
Dr inż. Karol Król \\ Uniwersytet Rolniczy w Krakowie \\ Katedra Gospodarki Przestrzennej i Architektury Krajobrazu \\ 30-059 Kraków, al. Mickiewicza 24/28 \\ e-mail:k.krol@onet.com.pl \\ website: http://homeproject.pl \\ ORICD: https://orcid.org/0000-0003-0534-8471
}

